Fordham University

Fordham Research Commons

\title{
How Much Does the Distance in Distance Education Matter? Our Students Speak
}

\author{
Manoj Pardasani \\ Adelphi University \\ Lauri Goldkind \\ Fordham University \\ Janna Heyman \\ Fordham University \\ Bronwyn Cross Denny \\ Sacred Heart University
}

Follow this and additional works at: https://research.library.fordham.edu/gss_facultypubs

Part of the Curriculum and Instruction Commons, and the Social Work Commons

\section{Recommended Citation}

Pardasani, Manoj; Goldkind, Lauri; Heyman, Janna; and Cross Denny, Bronwyn, "How Much Does the Distance in Distance Education Matter? Our Students Speak" (2012). Social Service Faculty Publications. 11.

https://research.library.fordham.edu/gss_facultypubs/11

This Article is brought to you for free and open access by the Graduate School of Social Service at Fordham Research Commons. It has been accepted for inclusion in Social Service Faculty Publications by an authorized administrator of Fordham Research Commons. For more information, please contact considine@fordham.edu, bkilee@fordham.edu. 
This article was downloaded by: [Goldkind, Lauri]

On: 27 April 2011

Access details: Access Details: [subscription number 936940073]

Publisher Routledge

Informa Ltd Registered in England and Wales Registered Number: 1072954 Registered office: Mortimer House, 3741 Mortimer Street, London W1T 3JH, UK

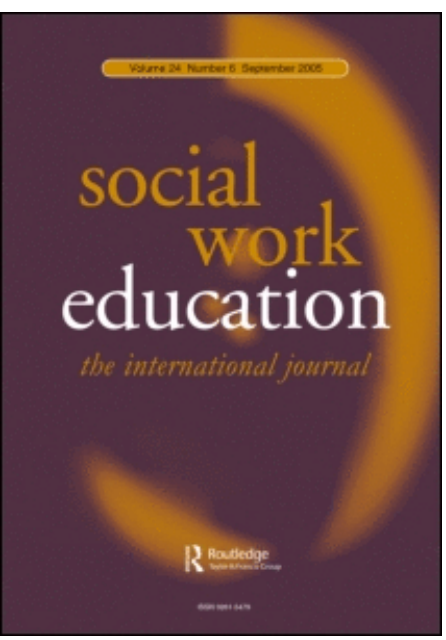

\section{Social Work Education}

Publication details, including instructions for authors and subscription information:

http://www.informaworld.com/smpp/title $\sim$ content=t713447070

\section{How Much Does the Distance in Distance Education Matter? Our Students Speak}

Manoj Pardasani ${ }^{\mathrm{a}}$; Lauri Goldkind ${ }^{\mathrm{a}}$; Janna C. Heyman ${ }^{\mathrm{a}}$; Bronwyn Cross-Denny ${ }^{\mathrm{b}}$

${ }^{\text {a }}$ Fordham University, USA ${ }^{\text {b }}$ Sacred Heart University, USA

First published on: 27 April 2011

To cite this Article Pardasani, Manoj, Goldkind, Lauri , Heyman, Janna C. and Cross-Denny, Bronwyn(2011) 'How Much Does the Distance in Distance Education Matter? Our Students Speak', Social Work Education,, First published on: 27

April 2011 (iFirst)

To link to this Article: DOI: $10.1080 / 02615479.2011 .573547$

URL: http://dx.doi.org/10.1080/02615479.2011.573547

\section{PLEASE SCROLL DOWN FOR ARTICLE}

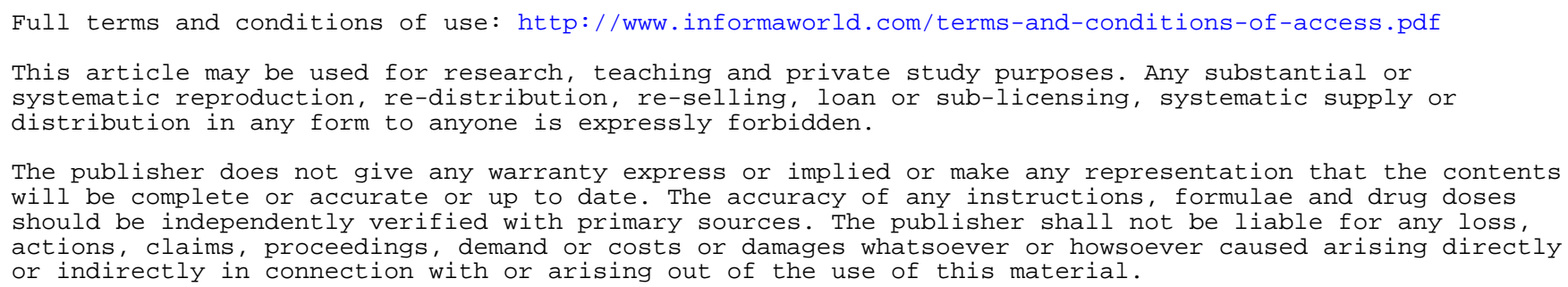




\section{How Much Does the Distance in Distance Education Matter? Our Students Speak}

\section{Manoj Pardasani, Lauri Goldkind, Janna C. Heyman \& Bronwyn Cross-Denny}

Distance learning programs in social work education have been growing exponentially throughout the United States. This study interviewed Master of Social Work (MSW) students enrolled in two synchronous distance-learning courses that employed a blended pedagogy, and evaluates their insights about the learning experience. For these two courses, material was presented via video conferencing and supplemented with online media at two campuses at a large school of social work. In order to give students a voice about their experiences, data were collected using semi-structured face-to-face interviews. Common themes included: autonomy, emotional connectedness, technological challenges, and knowledge acquisition. Both the strengths and challenges related to distance learning are discussed.

Keywords: Distance Learning; Distance Education; Social Work Education; Video Conferencing

There has been significant growth in distance learning programs throughout postsecondary institutions across the United States. Globally, there are estimated to be open universities (providing instruction through distance learning only) in over 50 countries [International Council of Open and Distance Education (ICDE), 2009]. ICDE (2009) estimates, that of the 120 million college/university level global student population, the majority of students from developing countries will be educated via distance learning. Srivastava (2002) reported that the countries with the largest

Manoj Pardasani, Lauri Goldkind \& Janna C. Heyman, Fordham University, USA; Bronwyn Cross-Denny, Sacred Heart University, USA.

Correspondence to: Manoj Pardasani, Associate Professor, Fordham University, Graduate School of Social Service, 133 West 60th Street, New York, NY 10023, USA. Email: mpardasani@fordham.edu 


\section{M. Pardasani et al.}

number of distance education programs were the US, Canada, India and Australia. These new technologies have radically changed the manner in which instruction occurs and learning is experienced (Siegel et al., 1998).

It is not surprising that a range of technological modalities for delivering a curriculum have also taken root in social work education (Allen and Seaman, 2009; Vernon et al., 2009). In a 1994 survey of the prevalence of distance learning in social work programs, Jennings et al. (1994) found that $11 \%$ of the programs reported utilization of distance education technology. A follow-up study in 1998 found that the number of programs incorporating distance education had jumped to $16 \%$ (Siegel et al., 1998). Recently, Vernon et al. (2009) examined distance learning courses and found that, for those programs that responded, $41 \%$ of the BSW and $52 \%$ of the MSW courses were delivering distance education courses and others planned to do so. Currently, there are at least five schools of education in the US that offer entire MSW degree programs via distance education (Vernon et al., 2009). Given this growth in distance education, it is critical for educators and social work programs to evaluate their impact on student learning, professional development and pedagogical experiences. Assessing the unique student experiences, challenges and needs related to distance education will provide valuable feedback for the design of effective distance education programs (courses, degrees etc.).

\section{Purpose of Study}

This study evaluates the learning experiences of Master of Social Work (MSW) students enrolled in two synchronous distance-learning courses which delivered content to students remotely via teleconference. For these two courses, classes were held via video conferencing supported by online media at two campuses of a large school of social work. Every session of the class was held via teleconference with students attending the class on two campuses simultaneously. The instructor was present on one campus and was connected to the other campus via video conferencing. The Spring semester course was comprised of 15 weeks of video conference instruction with each session being 1 hour and 50 minutes long, and the Summer session was comprised of eight weeks of teleconference instruction where each session was 3 hours and 30 minutes long. The study aims to explore students' personal experiences with their instructor, fellow students, and the technology, as well as to understand their preferences, concerns, and their perceived barriers to learning. The major research questions were:

1. What are the experiences of students in distance learning courses?

2. Are students' experiences different by the type of course?

3. Do students feel that their learning has been different because the course was a distance learning course?

The authors addressed the study questions via a qualitative approach: interviewing students who had been enrolled in the teleconference courses. All interviews were scheduled at the convenience of the student participants and were conducted 
in-person. No students were interviewed by their class instructor. Interview questions from this study are included in Appendix A.

\section{Literature Review}

Distance learning provides social work programs with the ability to offer students an array of choices in terms of both how they experience the social work classroom and where they attend classes. In the US, distance education programs were primarily created to increase enrolment in social work programs by accommodating 'nontraditional' students who may experience barriers to access (distance, transportation, employment obligations, etc.). Other reasons for distance education programs were the need to consolidate programs offered at satellite sites and conserve resources when two small, geographically separated sections of the same course could be taught by one instructor (Siegel et al., 1998; Collins, 2008; Ayala, 2009; Berger et al., 2009). Siegel et al. (1998) trace the development of distance education programs in the US to the early 1990s and state that the idea was initially met with 'fascination, reservation and caution' (p. 74). In the UK, Collins (2008) linked the development of distance education programs in social work to the early 1990s with the establishment of the Open Learning Foundation, a consortium of 23 universities (p. 425). According to Adams (1995), they came into existence because 'universities needed to address the declining proportion of resources available for each student, the increasing size of classes and the wider diversity of students' backgrounds' (p. 372). Collins (2008) added that another impetus for distance education was the demands for continuing education and training from social service agencies and professionals already working in the field. This then expanded from individual courses to entire study programs offered online.

Siegel et al. (1998) found that at least 15\% of social work programs (both undergraduate and graduate) incorporated some form of distance education in their course offerings. Wilke and Vinton (2006) found that about a quarter of MSW programs offered some form of distance education, and that about $15 \%$ offered at least one entire course online. Recently, Vernon et al. (2009) found that four out of 10 BSW programs and one out of two MSW programs offered online courses.

\section{Distance Education and Blended Learning}

Siegel et al. (1998) defined distance learning as 'a formal manner of teaching or instruction whereby the teacher and the learner are in separate locations most of the time' (p. 71). Similarly, Miller et al. (2003) define distance education as a 'formal, student-teacher arrangement in which the student and teacher are separated by space and/or time', thereby adding the dimension of time (p. 10). However, there is no singular definition or operationalization of distance education. Currently, distance education ranges from courses being taught at multiple locations simultaneously to web-based courses or a 'blending' or 'hybrid' of both traditional classroom instruction and information technologies. With the advances in technology, diverse tools such as 
synchronous and asynchronous Internet conferencing groups, in-class use of technology (e.g. 'smart rooms') and computer-based instruction have become common (Osguthorpe and Graham, 2003; Allen et al., 2007). In order to augment traditional face-to-face classroom teaching, interactive TV (ITV), also referred to as compressed video, interactive video or video conferencing, has become increasingly popular in the academic field (Forster and Rehner, 1998; Freddolino, 1998; Cauble and Thurston, 2000; Forster and Washington, 2000; Petracchi and Patchner, 2000; Schoech, 2000; Hicks, 2002; Seabury, 2002).

The diverse use of technologies and pedagogical tools in distance learning has given rise to a new term-blended learning. Ayala (2009) defined blended learning as 'the purposeful integration of traditional (i.e. face-to-face) and online learning in order to provide educational opportunities that maximize the benefits of each platform and thus more effectively facilitate student learning' (p. 277). The courses being evaluated in this study fit the definition of 'blended learning'.

\section{Distance Education Instructional Methods in Social Work Education}

Today, even the traditional classroom makes use of interactive material on the web, electronic message boards such as Blackboard, and other sources to enhance students' experiences (Ayala, 2009). This growth has also opened up new ways for students to learn as well as offering students alternatives towards addressing issues of geography, scheduling, and logistics (MacFadden et al., 2005; Jones, 2010).

Over a decade ago, Siegel et al. (1998) found that the most common systems for distance education delivery were television (satellite transmission) and compressed video (translation of analog signals into digital signals by a computer). Keeping pace with the rapidly increasing technology options, social work education has embraced diverse formats for its distance learning programs. Vernon et al. (2009) found that nearly one-third of all BSW programs (31\%) and half of all MSW programs (51\%) offered entire courses via the Internet. One in four MSW programs also offered courses via interactive television (ITV) to reach students in multiple locations. Approximately $19 \%$ of BSW programs and $12 \%$ of MSW programs utilized a combination of ITV and Internet/web technologies in their distance education offerings (Vernon et al., 2009).

\section{Outcomes of Distance Education in Social Work}

Siegel et al. (1998) found that as distance education options have increased, social work educators have begun to embrace this new strategy. To address the comparison of outcomes for traditional classes versus distance learning programs, York (2008) compared three modes of instruction in a graduate social work program including: traditional classroom; solely Internet; and a hybrid, which represented a combination of traditional classroom and Internet. She found that there were no differences with respect to knowledge, content, and student satisfaction among the three modes of instruction. Sprinkle (2009) also examined educator effectiveness between courses that 
were taught in a traditional classroom and those taught using distance learning, with the results showing no difference between the two approaches. Schoech and Helton (2002) also found no difference in satisfaction levels of students taught in the classroom versus Internet courses.

Of particular interest to this study, Thyer and Polk (1997) evaluated the experiences of two groups of students enrolled in a blended course (utilizing ITV) at the University of Georgia School of Social Work. Nine students were located on the main campus, while 11 students attended at a satellite location. Students at the main campus received three sessions of live instruction, while the students at the satellite location were connected via interactive television (ITV). Students at the satellite location received five sessions of live instruction (with the instructor in the room), while students from the main campus connected via ITV for those sessions. Students from both locations were asked to evaluate their experiences by assessing overall class quality, management of course technology and coordination aspects of the class. Thyer and Polk (1997) found no significant differences between the two groups of students in any of the dimensions measured. The only significant finding was that students, regardless of their learning experiences, showed a slight preference for live instruction versus the ITV experience (Thyer and Polk, 1997).

Another recent study of the differences between a traditional course format (live instruction) and one offered though a blended format of live instruction and ITV found no significant differences in outcomes between the two (Berger et al., 2009). The students surveyed reported that the ITV format did not compromise their learning, achieving course objectives or access to the instructor. Nevertheless, the authors found that, given a choice, students prefer to enroll in a live instruction course and were reluctant to take an additional distance learning course, unless their schedules or travel arrangements restricted their mobility (Berger et al., 2009).

\section{Challenges of Distance Education}

While there has been a growing body of literature comparing outcomes of distance learning and the traditional classroom, there has been limited information regarding in-depth students' experiences with distance learning courses (Berger et al., 2009). Researchers have identified three main categories of challenges encountered in the delivery of distance education-student concerns, instructor abilities and proficiencies, and availability of resources (Thyer and Polk, 1997; Siegel et al., 1998; York, 2008; Ayala, 2009; Berger et al., 2009; Kelly and Papadopoulos, 2009; Vernon et al., 2009; Jones, 2010).

With reference to students, studies have found that students prefer live instruction, appreciate the physical contact with an instructor and the face-to-face interaction with other students (Siegel et al., 1998; Berger et al., 2009; Jones, 2010). Even when live ITV is used as a modality, students feel less connected to those at a different site than their own (Berger et al., 2009). Another concern for students is the erratic functioning of technology or the difficulties encountered in using it (such as system outages, camera angles, inability to see the professor and other students simultaneously, sound quality, etc.) 
(Siegel et al., 1998; York, 2008; Berger et al., 2009; Kelly and Papadopoulos, 2009; Vernon et al., 2009; Jones, 2010). Finally, MacFadden et al. (2005), York (2008), Berger et al. (2009) and Kelly and Papadopoulos (2009) report that limited access, scheduling or lack of transportation were more likely to drive the selection of a distance education course rather than the subject of the course.

With reference to instructors, Ayala (2009) and Vernon et al. (2009) stress the importance of instructor preparation and their expertise and comfort with the utilization of varied electronic instructional technologies. Researchers also point to the importance of courses being specifically designed for this (distance education courses) modality use rather than teaching it in the same manner as a traditional classroom course (Thyer and Polk, 1997; Ayala, 2009; Jones, 2010). Finally, the availability of resources to support the instructor, the investment in technologies utilized and faculty buy-in are critical factors in the successful implementation of distance learning programs (Siegel et al., 1998; Vernon et al., 2009).

\section{Methods}

The authors received university Institutional Review Board approval for the research. The research was conducted with students from two classes that were involved in the distance learning approach at two campuses of a large school of social work. One class was a graduate nonprofit administration course which prepares students for practice as managers and leaders in social service agencies. The other class was a social work program evaluation course which focused on understanding and using different types of evaluation approaches to assess agency and community-based programs and services. Both the courses used lectures through video conferencing with supplemental online materials including video clips, document sharing via Blackboard (the university online program) and other written media and links, managed also via Blackboard. Instructional methods for these courses included lectures supported by PowerPoint slides, small group activities, discussion and case study material. Since these courses were among the first classes to use distance learning at this institution, the authors selected an exploratory approach to understand and uncover students' experiences. The authors met to plan, develop, and refine the semi-structured questions. Interview questions were created jointly by the four authors and included items such as:

- Tell me if you had some positive experiences with the distance learning aspect of this course?

- What, if any, in your opinion were the challenges of the distance learning aspect of this course?

- Thinking about this modality of course experience, how does this learning experience compare to other classes you have taken?

A complete accounting of interview questions can be found in Appendix A. 
Sample

A total of 25 students in the two classes were invited to participate in the project. In order to ensure confidentiality and self-determination, the investigator introducing the project and scheduling the interviews was not the students' instructor. The students ranged in ages from 25 to 45 , and were 25\% male and 75\% female. Racially, the students included in the sample were 60\% Caucasian/White and 40\% Black/African American or Latino/a. Greater demographic details regarding the student participants were not collected so as to protect study participants, given the small overall sample size.

\section{Procedure}

In order to promote the study and secure subject participation, the research was explained to the students at the end of the semester for each teleconference class. Students were invited to participate in a face-to-face interview by an interviewer (one of the four authors) who was not their instructor. The informed consent documents explained that possible participants had been selected as someone enrolled in distance learning courses in the Spring semester of 2009.

Student participants were interviewed by authors who were not the students' instructor so as to insure students' comfort and protect their ability to speak freely, without the pressure of a possible impact on course grades. Each semi-structured interview took approximately 30 minutes to complete. The interview included questions about the distance learning course, students' relationships with fellow classmates and the instructor, and the students' experience with using the technology. Participation was voluntary and students were informed that their professors would not know whether or not he/she participated in the study. Only the interviewer knew the identity of the participating student. A unique study identification number was assigned to the students who participated in the study. The interviewer used a digital recorder in order to most accurately reflect the students' responses. After receiving permission, the interviewer told the participants they would not use their name in the recording.

\section{Process}

All audio-taped interviews were transcribed by a trained transcriptionist. One of the authors $(\mathrm{JH})$ randomly reviewed selected portions of the tapes to verify the transcription. The software program ATLAS/ti was used for coding all of the transcripts. All four authors were involved in reviewing the transcripts. Open coding was used (Strauss and Corbin, 1998) to help identify concepts and their properties. As in the model outlined by Strauss and Corbin, the goal was to uncover common themes 'grounded' in the data themselves (Beard et al., 2009).

By reviewing the codes and memos and constantly comparing the data, themes and categories were initially developed. First, all four authors independently coded the data. The four authors then met to discuss the coding and themes that emerged. 
8 M. Pardasani et al.

After a series of discussions, consensus was reached. Next, the authors worked in pairs to review the data again.

The students' statements about their experiences with distance learning were compared to other students to understand the differences and similarities. Data from both classes were compared and reviewed by the authors. At the last meeting, the authors discussed the data and decided that they felt they had reached the point of saturation (Padgett, 1998). The authors exchanged drafts of the manuscript with each other to assure that the information was captured. Four themes arose from the process-autonomy; emotional connectedness; technological challenges; and knowledge acquisition.

\section{Findings}

Presented below are the authors' findings and key quotes that emerged from their analysis. Overall, four central themes emerged-autonomy; emotional connectedness; technological challenges; and knowledge acquisition. Autonomy in this case refers to students' sense of independence in terms of course taking and decision making as to how the knowledge or contents of their course was delivered. The notion of emotional connectedness as it arose in the interviews references students' relationships with each other and with the instructor. Technological challenges are those issues that emerged as a direct result of relying on the school's network and video conferencing hardware and other equipment in order for the class to go forward. Lastly, knowledge acquisition as it relates to our analysis discusses students' learning preferences and their own perspectives of themselves as learners.

\section{Autonomy}

Choice and some measure of control over their academic options were an important theme for the students. They frequently reflected that it was important for them to be able to have the right to decide what class they could take. Many students were not informed they were registering for a distance learning course. Some students may not have been able to take courses if the courses were not offered through the video conferencing approach.

After the choice about pedagogical modality (distance learning or not), a choice of instructor was also very important to students. In fact, most of the students cited that the professor was the reason they selected the course and that the distance learning portion was not a major consideration. Students felt that the course choice was important:

It would depend on how much I want to take the course. If it were the only opportunity to take this certain course with this certain professor that I would really want to take I would definitely do it.

I took the course number one because I really appreciate the professor and ... I also respect some of the students who were taking course.

Another student stated that taking the distance learning course was better than having 'to be told they have to go to the main campus'. One student noted that being able to take courses in her concentration was critical for her: 
That's the only way that the class is to be viable so without that option I would not have been able to have the curriculum at the [university] that I wanted to have. I would have had to choose a different concentration.

\section{Emotional Connectedness}

All students across the sample felt that they had adequate access to their professors with respect to contacting them about assignments and asking questions. However, students had mixed experiences about emotional connectedness with other students. Since video conferencing was used between the two campuses, during the interview some students referred to the students not on the campus as students on the 'other side', 'the far side', and the 'other end'. One student explained that there were challenges in 'getting to know your classmates' and that it was difficult to 'work in small groups with classmates from the other campus'. Another student felt emotionally connected to the group that they were with:

When the three of us on our side are extremely bonded probably more so if we were part of a larger class because you are sort of going through this new experience together. But as far as being bonded to the people on the other end of the screen that is a lot more difficult.

However, other students felt like it enriched their experiences. One student explained:

I guess the one aspect would be just really gaining some perspective on how other people are experiencing the course and experiencing the school in another area and you know how it may be different from our experience and what the culture may be there.

Another student recognized that:

you have at least some connectedness with being able to see them and them being able to see us. There that type of interaction but again not the same as face to face but better than an internet class.

\section{Technological Challenges}

All the students commented that technological challenges were present, but many students did not feel it took away from the content of the course material. One student stated:

I felt like I was in a Star Trek episode. I had to get used to the fact that the professor was not in the class which is part of my learning process ... so it was hard for me a little bit to acknowledge that the professor is somewhere else.

Another student acknowledge that the professor was

really good at making sure that she engaged us that she was constantly looking at the camera and talking to us and she tried her best in regard to having us be able to see what she wrote on the board but the way the screen is set up ..., it is just not conducive.

One student stated, 'Whoever set up the distance clearing didn't really seem to care ... they were dismissive'. The same student also felt that the professor helped to overcome 
the technological challenges and stated that 'The professor made a real effort to engage us'. Another student also recognized that for the professor it may be 'uncomfortablewho likes being on camera'.

\section{Knowledge Acquisition}

Students discussed a range of knowledge that they each acquired. With respect to course content one student stated

I don't think immediately about the long distance learning I think more about the content of the class and it was a fabulous class and it compared memorably to other courses. I'm not sure that the long distance component made it that much of a difference to me in thinking about it.

Another student stated that

Before taking this course if I were at an agency and it was job to evaluate a program or a plan for an evaluation I think I would have felt that I not qualified to do it and now I feel that I would know how to think about it and um how to approach it.

\section{Limitations}

With this type of research, generalization cannot be made about students' experiences in this course, however, insights about students' experiences can help to gather more information about what issues students feel are important in distance learning courses. While over $85 \%$ of the students who took the course volunteered to participate in the interviews, the experiences from those who were unable to participate due to time constraints and other personal reasons could have been similar or different experiences than their peers.

Students often expressed their experiences with the distance learning component of the course, but for many participants they expressed difficulty about separating out the components, because often the professor may have been the reason he/she took the course or why it was the learning experience was valuable. For one of the courses, there were only three students at the remote site and the small number of the cohort may have contributed to their overall learning experience.

However, because the method of delivery of this course was new to the school, students often wanted the interviewer to capture their stories and how important personal preference and being able to decide what courses they could take were to them. Although the authors used the multiple reviewer method for questionnaire design and data analysis, their personal biases may have influenced the choice of interview questions or the interpretation of the data collected.

\section{Discussion of Findings}

The issue of student autonomy was a recurrent theme throughout the interviews. Some students felt that they had no choice but to attend the distance learning course 
because of their location. In other words, some students found themselves at the site where they connected mostly via video conferencing and the instructor was in the same room as them on very few occasions. There was one of three main reasons offered for why they enrolled in such a course: no traditional classroom course being offered simultaneously, a professor they loved or transportation barriers (they could not make it to the campus where the same course but in a traditional classroom format was being offered). No students stated that they specifically chose a distance learning course because they were excited by the format. Our results are consistent with the findings of several researchers cited earlier. In their evaluation of student experiences with distance education, MacFadden et al. (2005), York (2008), Berger et al. (2009) and Kelly and Papadopoulos (2009) also found that the reason for selecting a distance learning or blended format course is precipitated by lack of choice or issues related to scheduling and transportation.

Some students stated that their experience had been positive and that they would enroll in a distance learning course in the future. Two students also reported that they could see the utility of such a format in their agencies for staff training purposes. However, many students stated that, given a choice, they would still enroll in a course taught in a traditional classroom format. Berger et al. (2009) found similar results in their evaluation of student experiences in two blended format courses.

Emotional connectedness was a critical factor in the students' evaluation of their experiences with the courses. Students stated that the ability to connect with their peers and the instructor was important to them. Some students stated that they did not feel like the students at another site were an integrated part of their own classroom setting. While they were able to see them on a television, hear them or engage in dialogue with them, they stated that they did not 'bond' with them in the same manner as students at their own site. This opinion was shared by students at both sites, but especially by students who were less likely to be in the room with an instructor or were smaller in number. In one of the courses, the students from both sites stated that they felt more connected to their peers when the instructor arranged for them to attend one specific class at one site midway through the semester. One student suggested that such opportunities should be offered at the beginning of the semester so that the students could get to know each other in an intimate setting. This was one finding that was not cited by other researchers in their respective studies.

However, Siegel et al. (1998), Berger et al. (2009) and Jones (2010) did report that students highlighted the significance of feeling connected to their instructor and having face-to-face time with them. Students in our study reported similar feelings. They strongly believed that both instructors were responsive to their needs and were readily available to them. Nevertheless, students who were less frequently in the same classroom as the instructor stated that they would have preferred to have more face-toface instruction time.

Several researchers have highlighted the critical role played by technology in the learning experiences of students enrolled in distance education courses (Siegel et al., 1998; York, 2008; Berger et al., 2009; Kelly and Papadopoulos, 2009; Vernon et al., 2009; Jones, 2010). The students in this study, especially in one of the courses being 
evaluated, expressed their irritation with sound disturbances, the small size of the classroom and limited camera movement as barriers to a satisfactory learning experience. Additionally, single television screens in each classroom prevented students at the remote site from seeing the instructor, other students and the board (or the computer screen) simultaneously. This caused some frustration and time delays for the students involved. Students reported that there was some disorientation initially with respect to paying attention to the instructor and fellow students from both sites, but they adapted very quickly to the multi-faceted environment and those distractions did not prove to be major hindrances.

Even though students preferred face-to-face time with an instructor and their fellow students, almost all students, regardless of their location, reported that their learning needs had been met sufficiently. Many students stated that, regardless of their location, they had learned 'a great deal' from both the courses and were satisfied with the course. This is similar to the findings reported by Thyer and Polk (1997), Schoech and Helton (2002), York (2008) and Sprinkle (2009) where no significant difference was found in learning between students in traditional and distance learning (including blended) formats. Some of the students also added that they felt comfortable with the use of technology (PowerPoint, cameras, voice monitors, etc.) and that they did not hinder their personal learning. Students stated they would recommend a similar distance education (blended format) course to their peers. However, it was difficult to assess whether their positive experience with such a course arose from the content learned or from their respect for the instructor or both. When asked about their learning experiences, some students expressed their appreciation for the instructor which had prompted them to register for the course in the first place.

Finally, instructor skill and expertise was another significant factor that influenced student experiences. Students stated that their instructors were proficient with the use of technology and had effectively designed their courses to meet the needs of the blended format. Additionally, students reported that the instructors were mindful of the needs of the students at both sites during a class, and were responsive to their needs and concerns. Several students also stated that the instructors possessed extensive knowledge of the subject matter and this made for a positive learning experience. The only complaint for some of the students was related to the perceived lack of cooperation from technological support services who did not always respond promptly to their concerns.

\section{Implications and Areas for Further Investigation}

The teleconference model of delivering course content has some attractive factors from the standpoint of administrators and students. However, caution must be advised when universities and schools of social work rush to implement new technologies without understanding their impact on students and instructors. This research revealed four themes, each of which merits further consideration: autonomy, emotional connectedness, technological challenges and knowledge acquisition. 
Students repeatedly expressed a desire to be informed of the fact that their course might not take place in a traditional learning environment. The students interviewed here made a significant emotional investment in selecting courses from the considerations of logistics, where a class was being offered, and what they knew about the instructor, and they had clear preferences as to how courses were made available to them.

Social work being a relationship building profession, one is not surprised that the emotional connectedness and social dimensions of learning were important to the students interviewed. Students valued the opportunity to meet in real-time and have face-to-face interactions with their colleagues on the other side of the television screens. An area of future investigation might include trying to understand students' satisfaction with distance learning in courses with no face-to-face interaction versus courses which offer the possibility of some real-time and space meetings as one class group.

The technological challenges experienced by these students were real and detracted from their learning experiences. Administrators need to understand that significant investments in the hardware that support a successful distance learning experience as well as training for instructors on how to maximize the available technology is critical to the success of distance education classes.

Students' responses concerning knowledge acquisition are encouraging. Despite being in a potentially challenging learning environment, the students sampled here consistently responded that the content delivered in the course was more significant than the mode of content delivery. This is a point worth noting for administrators as which instructors get assigned to navigate the teleconference modality are decided.

\section{Conclusion}

The use of technology to deliver social work education is no longer a cutting edge phenomenon. The range of distance learning models and technologies has become part of the fabric of our graduate and undergraduate programs. It behooves us as a relationship based profession to understand how the various distance education models and the synchronous teleconferenced delivery of courses impacts our ability to connect with our students, to model relationship building and encourage students' peer relationship building in our courses. For the students interviewed for this research, prior notice or lack of such notice that a class would be delivered via teleconference was an important factor in their satisfaction with the experience. Overall, students' regard and respect for individual instructors over-rode most other concerns in terms of learning to be comfortable in the teleconference environment.

\section{References}

Adams, R. (1995) 'A consortium approach to open and distance learning development in the health and social services in Britain', Developing the Professional Community, pp. 371-374. 
Allen, I. E. \& Seaman, J. (2009) Learning on Demand: Online Education in the United States [online]. Available at: http://www.sloan-c.org/publications/survey/pdf/learningondemand.pdf, accessed 18 June 2010.

Allen, I. E., Seaman, J. \& Garrett, R. (2007) Blending In; The Extent and Promise of Blended Education in the United States [online]. Available at: http://www.sloan-c.org/publications/survey/ blended06, accessed 18 June 2010.

Ayala, J. S. (2009) 'Blended learning as a new approach to social work education', Journal of Social Work Education, vol. 45, no. 2, pp. 277-288.

Beard, R. L., Fetterman, D. J., Wu, B. \& Bryant, L. (2009) 'The two voices of Alzheimers: attitudes toward brain health by diagnosed individuals and support persons', The Gerontologist, vol. 49, no. S1, pp. S40-S49.

Berger, R., Stein, L. \& Mullin, J. B. (2009) 'Videoconferencing: a viable teaching strategy for social work education', Social Work Education, vol. 28, no. 5, pp. 476-487.

Cauble, A. E. \& Thurston, L. P. (2000) 'Effects of interactive multimedia training on knowledge, attitudes, and self-efficacy of social work students', Research on Social Work Practice, vol. 10, no. 4 , pp. $428-437$.

Collins, S. (2008) 'Open and distance learning in qualifying social work education in Britain and the USA: celebrating diversity and difference?', Social Work Education, vol. 27, no. 4, pp. 422-439.

Forster, M. \& Rehner, T. (1998) 'Part time MSW distance education: a program evaluation', Computers in Human Services, vol. 15, no. 2/3, pp. 9-21.

Forster, M. \& Washington, E. (2000) 'A model for developing and managing distance education programs using interactive video technology', Journal of Social Work Education, vol. 36, no. 1, pp. $147-158$.

Freddolino, P. P. (1998) 'Building on experience: lessons from a distance education MSW program', Computers in Human Services, vol. 15, no. 2/3, pp. 39-50.

Hicks, S. (2002) 'Connecting aboriginal learners in remote communities: an online social work course', Journal of Technology in Human Services, vol. 20, no. 3/4, pp. 267-281.

International Council of Open and Distance Education (ICDE) (2009) Global Trends in Higher Education, Learning and Distance Education [online]. Available at: http://www.icde.org/ filestore/Resources/Reports/FINALICDEENVIRNOMENTALSCAN05.02.pdf, accessed 1 September 2010.

Jennings, J., Siegel, E. \& Conklin, J. J. (1994) 'Social work education and distance learning: applications for continuing education', Journal of Continuing Social Work Education, vol. 6, no. 2, pp. 3-7.

Jones, P. (2010) 'Collaboration at a distance: using a Wiki to create a collaborative learning environment for distance education and on-campus students in a social work course', Journal of Teaching in Social Work, vol. 30, pp. 225-236.

Kelly, F. \& Papadopoulos, I. (2009) 'Enhancing the cultural competence of healthcare professionals through an online course', Diversity in Health and Care, vol. 6, pp. 77-84.

MacFadden, R. J., Moore, B., Herie, M. \& Schoech, D. (2005) 'Web-based education in the human services: content and connection', Journal of Technology in Human Services, vol. 23, no. 2, pp. 1-9.

Miller, P. A., Walker, J. \& Ayala, J. (2003) 'Technology integration as a transformative catalyst and tool', International Journal of Learning, vol. 10 [online]. Available at: http://ijl.cgpublisher. com/product/pub.2037/prod.2230, accessed 19 August 2010.

Osguthorpe, R. \& Graham, C. (2003) 'Blended learning environments; definitions and directions', Quarterly Review of Distance Education, vol. 4, pp. 227-233.

Padgett, D. (1998) Qualitative Methods in Social Work Research: Challenges and Rewards, Sage Publications, Inc., Thousand Oaks, CA. 
Petracchi, H. \& Patchner, M. E. (2000) 'Social work students and their learning environment: a comparison of interactive television, face-to-face instruction, and the traditional classroom', Journal of Social Work Education, vol. 36, no. 2, pp. 335-346.

Schoech, D. (2000) 'Teaching over the Internet: results of one doctoral course', Research on Social Work Practice, vol. 10, no. 4, pp. 467-486.

Schoech, D. \& Helton, D. (2002) 'Qualitative and qualitative analysis of a course taught via classroom and internet chatroom', Qualitative Social Work, vol. 1, no. 1, pp. 111-124.

Seabury, B. A. (2002) 'COW: Conference on the Web', Journal of Technology in Human Services, vol. 20 , no. $3 / 4$, pp. $231-244$.

Siegel, E., Jennings, J., Conklin, J. \& Napoletano Flynn, S. A. (1998) 'Distance learning in social work: results and implications of a national survey', Journal of Social Work Education, vol. 34, no. 1, pp. $71-80$.

Sprinkle, J. E. (2009) 'Student perceptions of educator effectiveness: a follow-up study', College Student Journal, vol. 43, no. 4, pp. 1341-1358.

Srivastava, M. (2002) 'A comparative study on current trends in distance education in Canada and India', Turkish Online Journal of Distance Education, vol. 3, no. 4 [online]. Available at: http:// tojde.anadolu.edu.tr/tojde8/articles/srivastava.htm, accessed 1 September 2010.

Strauss, A. \& Corbin, J. (1998) Basics of Qualitative Research, Sage, Thousand Oaks, CA.

Thyer, B. A. \& Polk, G. (1997) 'Distance learning in social work education: a preliminary evaluation', Journal of Social Work Education, vol. 33, no. 2, pp. 363-368.

Vernon, R., Vakalahi, H., Pierce, D., Pittman-Munke, P. \& Adkins, L. F. (2009) 'Distance education programs in social work: current and emerging trends', Journal of Social Work Education, vol. 45 , no. 2 , pp. $263-275$.

Wilke, D. \& Vinton, L. (2006) 'Evaluation of the first Web-based advanced standing MSW program', Journal of Social Work Education, vol. 42, no. 3, pp. 607-620.

York, R. (2008) 'Comparing three modes of instruction in a graduate social work program', Journal of Social Work Education, vol. 44, no. 2, pp. 157-172. 


\section{Appendix A: Distance Learning Interview Questions}

The first set of questions is about your experiences with the distance learning aspect of the course:

1. Could you please tell me if you had some positive experiences with the distance learning aspect of this course? If so, could you please elaborate?

2. What, if any, in your opinion were the challenges of the distance learning aspect of this course? If so, could you please elaborate?

3. Please describe your experiences of connectedness to your colleagues in this course.

4. Please describe your experiences of connectedness with the professor in this course. Should we define or explain 'connectedness'?

5. Please explain if you think this course has changed your perspective about building relationships with others in terms of ...?

6. Describe your experiences with the technological aspects of this course?

7. Having been through this distance learning course would you take additional learning courses? Why?

8. If you were to replicate a portion of this distance learning course, what would be the one component you would want other social work students to experience?

9. Thinking about this modality of course experience, how does this learning experience compare to other classes you have taken?

Now I would like to ask you some about the course itself:

10. Could you please explain why you took this course?

11. Please reflect about the course content and describe what social work practice skills you believe that you have learned in this class?

12. If you are in the field, could you please explain how this course has supported or not supported your field experiences?

13. Thinking about your skill level before taking this course and your skill level now, describe the areas where you believe you have grown as a professional.

14. If you were to conduct a training or workshop in the future for clients or peers, what aspects of this class (ideas, methods, technological tools, etc.) would you replicate or adapt? 